\section{BMJ Paediatrics Open}

\title{
Right of children to be heard
}

\author{
Donna Koller
}

To cite: Koller D. Right of children to be heard. BMJ Paediatrics Open 2021;5:e001161. doi:10.1136/ bmjpo-2021-001161

Received 15 October 2021 Accepted 22 November 2021

\section{Check for updates}

(c) Author(s) (or their employer(s)) 2021. Re-use permitted under CC BY-NC. No commercial re-use. See rights and permissions. Published by BMJ.

Early Childhood Studies, Ryerson University, Toronto, Ontario, Canada

Correspondence to Dr Donna Koller; dkoller@ ryerson.ca
Children now comprise $30 \%$ of the world's population. ${ }^{1}$ In one way or another, the COVID-19 pandemic has altered the life of every child on the planet. Children have experienced school and childcare closures, limited play and social interactions, increases in domestic violence, abuse, poverty-and some have experienced the profound loss of losing a loved one. ${ }^{2}$ The pandemic has exposed the fragility of children's lives and has profoundly threatened their fundamental human rights.

Many of the global and long-term consequences on children's social, emotional and physical well-being are unknown, but it is already clear that child well-being and pandemic management require urgent and full attention. Even during a pandemicand perhaps especially during a pandemicwe must find ways to elevate the discourse around children's rights and uphold the ethical and moral imperatives set out in the United Nations Convention on the Rights of the Child (UNCRC). ${ }^{3}$

Among all childhood rights, being listened to may be the most important, and is a central tenet of the UNCRC (Article 12). Children can only participate and develop social agency if adults listen to them. By listening to children, we can learn about them and what they believe is essential for their health and well-being. This is particularly important in the current social context, in which the pandemic has increased social inequities and children have lost significant developmental opportunities.

\section{CHILDREN'S RIGHT TO BE HEARD IN RESEARCH}

Research can provide opportunities to listen to children. However, researchers who describe findings based on the 'voices' of children may mistakenly assume their data represent authentic child perspectives. In reality, power differentials between adults and children can influence what both parties convey, and the lack of reference to a diversity of child perspectives and lived experiences is troubling. Particularly problematic is the ongoing use of parents as proxies for children's viewpoints.

Research methods employed with children often limit opportunities for conversational listening, which require building trust, mutual respect and voluntary engagement. Adult researchers have collected vast amounts of data from expedient large-scale surveys during the pandemic. These data can be informative and instructive from a policy and practice perspective, but the delivery of surveys through social media makes them inaccessible by many marginalised children with limited abilities or those who lack access to technology. These surveys are also unlikely to yield data related to how children adapted to the crisis, what was meaningful to them or whether they experienced any positive outcomes because of the pandemic. Therefore, it is important to design research methods that include evaluations of child recruitment, and to ensure that approaches to data collection are ethically sound and supportive of children's diverse abilities and perspectives. ${ }^{4}$ Otherwise, any attempts to promote children's right to be heard may be inadvertently undermined by the research methods employed.

Carnevale argues for a thick conception of children's voices. ${ }^{5}$ From this perspective, children are relationally embedded, so understanding their voices as agential expression requires awareness of their social context. Qualitative approaches using hermeneutical frameworks can illuminate what is meaningful for a child in a particular context, and methods designed to capture a child's unique ways of communicating can promote the inclusion of children who are young, disabled or who come from marginalised backgrounds. Children's expressed will and intent can include several dimensions: audible sounds and words, facial expressions, body language, 
play, artwork, music and even silence. For example, the use of picture communication symbols (eg, eye pointing), creative art-based approaches and other visual methods (eg, photo-elicitation) can enable the range of children's communication, cognitive and physical impairments to be accommodated. ${ }^{6}$ Research with young and diverse children can be challenging, but it is critical to provide equal opportunities for all children to be heard.

\section{REVISITING CHILDREN'S RIGHTS AND RESPONSIBILITIES}

When talking and listening to children in research and practice, adults should explore ways to provide opportunities for children's self-reflection and evolving identity. Children's rights are primary and unconditional, but another issue to consider is children's responsibilityparticularly in a pandemic. Although previous literature has cited concerns about over-emphasising children's responsibilities and how this might diminish their rights, Howe and Covell have consistently demonstrated the importance of building an understanding of responsibility from the child's own vantage point. ${ }^{7}$ They have clearly shown that children are capable of understanding the link between rights and responsibilities in reference to their own lives.

In my own research, I always ask child participants what is important to them, and whether they believe they have a 'job' to do on a range of issues. Instead of imposing an adult framework, I explore their views on serious issues and how these relate to children and their role. What is meaningful to them and how do they perceive their responsibilities within their family, school and community?

During the current pandemic, children are experiencing a rare and significant event that features a collective sense of responsibility. In this way, COVID-19 provides a novel opportunity to explore children's own notions of responsibility. During the 2003 SARS pandemic, and now during COVID-19, I asked children about their role and whether they believed that only grownups should take care of the problem. ${ }^{89}$ Both of these studies yielded clear findings: children inherently understood that they had a right to participate and a responsibility to do their part. They expressed the need to wear masks, wash hands and the collective obligation to protect others from getting sick-and they were keenly aware of what was at stake, as they discussed fears of losing a loved one.

Meaningful discussions enable children to share a range of experiences during the pandemic, including positive ones like spending more time with family, playing with pets and being able to adapt their play during lockdowns. Listening to children in this way leads to rich dialogue and the actualisation of ethical research methods and outcomes. Specifically, this approach directly supports children's participation rights and acknowledges the ethical importance of listening to children and the due weight they are accorded under Article 12 of the UNCRG. ${ }^{3}$

Children are part of a collective whole. Pandemics can teach us important life lessons about what it means to exercise rights, take action and respect the rights of others. Children have both rights and responsibilities, and they must be encouraged to play an active role in delineating their own responses to societal challenges. As child rights advocates, we must elevate and advance the art of engaging and listening to all children using approaches that promote their social agency and participation in the world around them.

Twitter Donna Koller @AllKidsIncluded

Contributors I am the sole author of this editorial.

Funding The authors have not declared a specific grant for this research from any funding agency in the public, commercial or not-for-profit sectors.

Competing interests None declared.

Patient and public involvement Patients and/or the public were not involved in the design, or conduct, or reporting, or dissemination plans of this research.

Patient consent for publication Not applicable.

Ethics approval This study does not involve human participants.

Provenance and peer review Commissioned; externally peer reviewed.

Open access This is an open access article distributed in accordance with the Creative Commons Attribution Non Commercial (CC BY-NC 4.0) license, which permits others to distribute, remix, adapt, build upon this work non-commercially, and license their derivative works on different terms, provided the original work is properly cited, appropriate credit is given, any changes made indicated, and the use is non-commercial. See: http://creativecommons.org/licenses/by-nc/4.0/.

\section{ORCID iD}

Donna Koller http://orcid.org/0000-0001-8561-5618

\section{REFERENCES}

1 United nations department of economic and social Affairs population dynamics, 2019. Available: https://population.un.org/wpp/Graphs/ Probabilistic/POP/0-14/900

2 Raman S, Harries M, Nathawad R, et al. Where do we go from here? a child rights-based response to COVID-19. BMJ Paediatr Open 2020;4:e000714.

3 United Nations. United nations convention on the rights of the child. Geneva: United Nations General Assembly, 1989.

4 Graham A, Powell M, Taylor N. Ethical research involving children. Florence: UNICEF Office of Research - Innocenti, 2013.

5 Carnevale FA. A "Thick" Conception of Children's Voices: A Hermeneutical Framework for Childhood Research. Int J Qual Methods 2020;19:160940692093376-9.

6 Stafford L. 'What about my voice': emancipating the voices of children with disabilities through participant-centred methods. Child Geogr 2017;15:600-13.

7 Howe RB, Covell K. Miseducating children about their rights. Educ Citizsh Soc Justice 2010;5:91-102.

8 Koller D, Nicholas D, Gearing R, et al. Paediatric pandemic planning: children's perspectives and recommendations. Health Soc Care Community 2010;18:369-77.

9 Koller D, Grossi M, Van den Heuvel M, et al. Hiding and Seeking: Children's lived experiences during COVID-19. Children Soc. In Press 2022. 